\title{
Gender, Migration and Citizenship across West African Frontiers as Portrayed in Selected (Yoruba) Nollywood Films
}

\author{
Olufadekemi Adagbada PhD \\ Department of Nigerian and Foreign Languages and Literatures \\ Faculty of Arts, Olabisi Onabanjo University \\ Ago-Iwoye, Ogun State, Nigeria.
}

\begin{abstract}
Presently, being modern is associated with movement. As such, staying in one place may appear anachronistic. People move in search of better living conditions. In the past, trade was a major reason for migration. National and local tragedies like war, famine, economic mismanagement, political unrests and instabilities, have also brought about displacement and migration. Migration may be intra-state or inter-state. Sociologically, race, gender and other identity categories have always been vestiges of bias against, and domination of migrants, to exclude or marginalize them. My objective in this study is to examine the lot of the females as migrants within West African states as portrayed in selected (Yoruba) Nollywood films. Some of my findings are that the film producers do not highlight or bring to the fore, the importance of proper documentation about migrants; that the West African frontiers are porous; that language barriers affect the welfare of migrants and more essentially, female migrants' worse condition in form of rape, forced labor, spousal violence and child care responsibilities. All these challenges are threats to the very purpose of ECOWAS. My suggestions are that there should be proper policing at the frontiers, that detailed and effective documentation and monitoring of the (few) individuals or group migrants that a country of refuge can conveniently cater for, be ensured. There should also be recognition and acceptance of certificates and diplomas possessed by any citizen of the ECOWAS state in any of the participating states. Financial aids can be given to unemployed migrants to become self-employed. Above all, forced displacement of persons must be drastically reduced by national leaders doing the needful politically, economically and socially, to improve the living conditions of their citizens.
\end{abstract}

Keywords: migration, women, vulnerability, acceptability, welfare

\section{INTRODUCTION}

'Migration', which Udo (in Ilésanmí 2016) sees as a rational behaviour, is the process of humans, birds or animals moving (periodically) from one place to another, in search of better living conditions when a place of domiciliation becomes uncomfortable as a result of ecological change or draught, for instance. To Ilésanmí (2016), migration is a common and natural phenomenon all over the world, and that the movement of man from one place to the other is as old as man himself. Humans, specifically and sociologically in modern times, migrate to live in a destination country of which they are neither natives nor possess citizenship, in order to settle with the intention of temporary or permanent residency, naturalization or taking up employment as migrant workers. The employment so sought may be permanent or otherwise. The non-economic push-effects that can make people migrate from one country to another include war, persecution (religious, political or otherwise), ethnic cleansing or international marriages. Apart from academic pursuits, economic push factors (especially for labour) that make people migrate include escape from poverty, differentials in wages rate and desire to learn on the job where there is better technological advancement. Migration may also be mandatory as in the cases of religious missionaries, diplomatic services or employment with 
transnational establishments. According to statistics, as of 2015, the number of international migrants has reached 244 million globally ${ }^{1}$. Migration therefore is responsible for the emergence and development of many settlements in the world.

\section{Rationale}

The way migrants are treated in host countries is a topic constantly under debate in the whole world. This is because more often than not, migrants' human rights are violated. The increase in global migration creates a possible clash between ideas of nationality and citizenship. 'Nationality' is a cultural community of people who believe that they have a common heritage and a common destiny (Castles 2000). However, identities change according to historical time period and location. Displaced persons as a result of war, natural disaster or political persecution, who decide to migrate for safety, are not likely to enjoy the rights and privileges they had before in their home state; they are now refuges in a foreign land. The focus of this study is to examine the experiences of the male, female and children as refugees in West African States, especially during their sojourn in Nigeria.

\section{REVIEW OF LITERATURE}

Migration has both causes and consequences. Cohen (2006) believes that increase in migration globally; that is the coming into contact of different people from different ethnic backgrounds can reduce the usual conflict and distrust between people, thus creating cosmopolitanism. Generally, cosmopolitans (people who have migrated or traveled extensively) tend to relate to people of another race, ethnicity or colour easily than those who have not traveled widely. On the other hand, Castles and Kosack (Haralambos et al 2008:155) are of the opinion that the richer European nations have exploited the poorer nations of the world, causing their underdevelopment. From colonial times onward, the 'third world' has been used as a source of cheap, easily exploited labour and cheap raw materials. By the 1930s, colonies and ex-colonies covered 84.6 percent of the land surface of the globe. Only parts of Arabia, Persia, Afghanistan, Mongolia, Tibet, China, Siam and Japan had never been under formal European government (Ania Loomba 2005:3). According to these Sociologists, the colonies were not allowed to develop, or in some cases, are unable to maintain their industries, which compete unfavourably with those of the Europeans. The impoverished people then become a reserve army of cheap labour for the capitalist nations.

The host community is at a great advantage in migration. This is because those who migrate are usually young and agile, thus they are a valuable resource. The society or nation into which migrants were born and nurtured with the little resources they have, will not have their citizens contribute to the creation of wealth for their nation by the time they grow up and migrate. To Castle and Kosack therefore, migration is a form of development aid for the migration countries, because these countries are able to take advantage of labour which cost them virtually nothing to nurture.

\section{METHODOLOGY}

This study was carried out by examining gender, migration and citizenship as portrayed in selected Yoruba films that are themed on the issue. The theoretical frame work on which this study hinges are two. The sociology of migration in the views of Castle (2000), Potts (2002), and Cohen (2006); to the effect that migration is better viewed from below, that is in the perspective of the migrant. This is because migrants are used as a reserve army of cheap labour. The second theory is the Vindication of Women's Rights in the opinion of Grewal and Kaplan (2002); that women and children suffer the worse in migration. 


\section{Migration and Citizenship along the West African Coast.}

Prior to the struggle for, and the partitioning of West African territory by the European colonists, identities of citizens were fluid. They were not fixed essences locked into differences which were permanent for all times. People moved freely across sister 'nations', trading and making domiciliation. The Yoruba of South West Nigeria for instance, have been long distance traders who sold their wares as far as Congo, Senegal, Togo, Ivory Coast and the Gambia. They even acquired the financial (and cultural) resources for further migration across the Atlantic (Falola 2012:11-14).

The artificial boundaries put in place by colonists as mark of ownership, have made citizens from one state in West Africa aliens in the other states. This continues to be so, even after the independence of the states from their colonial masters. Colonialism has left a legacy of poverty and political instability. There have been wars and political instability (largely due to neocolonial factors) in the former colonies, resulting in the redrawing of boarders and new political regimes. All these have resulted in severe displacement of many people who became homeless, unwanted and endangered. These have led to the institution of travelling documents that are meant to regulate and police arrival into and departure from one nation state to another.

Political and socio-economic issues can bring about threats to the acceptance and tolerance between host-nations and migrants. When (privileged) migrants (as labour force) begins to increase and try to ascertain citizenship rights and/or when their number threatens the employment and social welfare of their hosts, hostility sets in. Examples of this are the Indigenization Decree of 1969 which brought about a mass expulsion of thousands of Yoruba back home to Nigeria from Ghana, and the recent xenophobic experiences of migrants in South Africa.

Many Africans including Nigerians continue to migrate to South Africa and other countries in search of greener pasture due to the harsh economic situation in their homeland. In the past few weeks, the attacks seem to have risen sharply. At the last count, over 35 shops belonging to immigrants were reportedly looted in Pretoria, the South African capital ${ }^{2}$. The Nigeria Union in South Africa on Tuesday 22 $2^{\text {nd }}$ of March 2017 said five Nigerians had been attacked in Polokwane, Limpopo Province in renewed xenophobic attacks. Collin Mgbo, the Secretary to the Union in the province told the News Agency of Nigeria (NAN) on telephone that three of the five Nigerians were in critical conditions ${ }^{3}$.

West African Countries are more positively disposed to giving refuge to displaced people, especially through the auspices of the Economic Community of West African State (ECOWAS) the African Union (AU) and the United Nations (UN). A very good example is the Orù Refugee camp established in 1990 in Ògùn State, Nigeria, where Liberians, Sierra Leoneans and other West Africans who left their countries as a result of war and economic hardships were housed, until about five years ago when they were encouraged to return to their home states or naturalize and be integrated into their host community, albeit under stringent conditions.

In considering the citizenship of migrants, Cohen (2006) has opined three basic categories. These are Citizens, Denizens and Helots. Citizens are those who have full nationality by virtue of birth or naturalization, established migrants who have acquired citizenship rights or refugees who have been accepted as being legitimate under the 1951 Geneva Convention. People in this category may not enjoy full citizenship rights like voting during elections, but they can be employed and find it possible to enjoy lawful benefits and protection like other (natural) citizens. The denizens are the migrants who have some rights in the country they 
more into, or are accepted and welcome without recognition as full citizens. Such people include those who have dual nationality, recognized asylum seekers and special entrants who are permitted to stay for particular reasons. Some privileged Denizens do well paid jobs. Many of them are expertrates, consultants and technocrats (Haralambos et al 2008: 157 - 158). The Healot include illegal migrants, people with expired travel documents, asylum seekers who are yet to be accepted and unskilled workers. Migrants in this category are most vulnerable to exploitation. Females are more than the males as Healots (Crenshaw 2002). Most of these women are used to tedious work in the household and they continue to do so in their new settlement; manufacturing many essential goods consumed by the family and nurturing children, apart from the meager wage they earn in a labour market that is race and gender stratified. Chances of improved life style are often very slim for them because in most cases they are illiterates/semi-illiterates and unskilled. Domestic services like live-in servants, laundresses and nannies are the most common employment for them.

(Yorùbá) Africans are generally warm, receptive, kind and hospitable to visitors and even strangers. This attitude is an essential part of the code of good behavior-Omolúàbí' (a virtuous person). Traditionally among the Yoruba, a guest from afar, no matter how unexpected his/her visit may be, he/she is welcomed by the host for as long as he/she cares to stay. The guest's sense of propriety will however warn him/her against prolonged stay.

The colonial, post-colonial and neo-colonial political and economic experiences of the people in West Africa continue to manifest in their poor living conditions. Political instability and downward trends in national economy in most of the former colonies, have made most of the younger generation to leave their nations in search of greener pastures, while the older ones have resorted to accepting their faith. The older generations at home are so impoverished that their capability to remain kind and hospitable to guests and strangers have waned. The hostmigrant relationship in West Africa is thus challenged by the poor economic conditions of virtually all the former colonies. If refuge is even granted to 'brothers and sisters' from troubled zones, the assistance cannot be for long without additional aid and support from foreign organizations like the UN, UNESCO, Red Cross and the likes. This is because each West African state has challenges like mass unemployment, inadequate housing schemes, hunger and acute shortage of functional social amenities like electricity, water, good roads, schools and health facilities.

\section{Histrio-sociology of the Films Under Study}

In its basic purpose of entertainment (for edification), literature reflects what obtains in the society where it is produced; revealing the hopes, desires, aspirations, inter-relationships, beliefs, world-view and especially the experiences of a people. This is why Bamidele (2000:3) refers to Georg to have stressed that it (literature) offers historical social process or background, in which specific individual as characters struggle against specific environment and times. Adagbada (2014) has observed that the derivative source of the themes and subthemes of films (and texts) more often than not, is metafictional. The experiences expressed in a film may be personal or communal. If personal, they may be what have been in reality experienced by the author/script writer/film producer, or that which is desired/fancied/abhorred and thus imaginable ${ }^{4}$. Communal occurrences and experiences over the years become part of the (oral) history of a people, whether such experiences were positive, elevating and aided progress and development, or they mark a sad, retrogressive and inhibitive era in the people's social, political, economic or cultural evolvement. It is these experiences that literary artists consciously or otherwise hinge on for their literary 'creations'. 
Auters' ${ }^{5}$ adaptations/creativity can bear near or absolute fidelity to the original incident (whether they be oral or documented), or they may be borrowed, transformed or intersected (Adagbada 2008). None of the three films under study have existing literary texts (known of by the present writer) prior their productions. However, related literature in forms of hard copy and electronic books, newspapers and journals abound from where film themes and sun-theme can be sourced ${ }^{6}$. While the major issues as they concern migration, displacement, citizenship, and gender in Ėèku Idá7 (Sword of vengeance) and Aya mi Òwọ́n (Madam dearest) bear basically true fidelity to the common knowledge and experiences of many people in West African states, Àbèní ${ }^{8}$ is an attempt of transformation by reproduction of the original sociology of the relationship among the citizens of seamless West African 'states', prior to their assimilations by the colonists. This is achieved by giving the film further elaborations on geographical, sociological and cultural information, with embellishments of practices that were not common or known then ${ }^{9}$, but which are intended to give relative meanings to the ways of life in the recent past and in contemporary times.

The main themes of Aya mi ộwọn and Èèku Idá are based on the social and economic consequences of the sojourn of Ghanaians and Liberian refugees in Nigeria around the late 1970s to mid-1990s and mid-1990s to around 2010 respectively. Àbèní's theme of elopement across two countries by two young lovers, whose nuptial intentions are being threatened by a father's selfish intention, has its background situated in pre-colonial times in West Africa as earlier discussed.

\section{The Readings ${ }^{10}$}

The refugees who are in the lead roles of the films under study are neither "Citizens" nor "Denizens", but "Healots" in Cohen's (2006) categorization. Kwesi and Daniel in Aya mi ọ̀wọ́n (Madam Dearest) - henceforth referred to as AMO, have neither official documents nor letters of employment in transnational establishments to show for their residency in Nigeria. This is evident in Daniel's submissive response to Șèyís threats of handling him over to immigration officers, if he does not leave for Ghana immediately, without the son he sired for Bùkọlá, his boss' wife. It goes thus:

Sèyí: $\quad$ Șebí oore ló șe?... Màá ba tiẹ jẹ́ (Was it not help you rendered?..I will destroy you).

Daniel: $\quad$ I am an ECOWAS citizen, I have rights to move across West Africa.

Șèyí: $\quad$ Àbí o ò ranti bí o șe débi? Màá fi immigration ba tì jệ...

(Have you forgotten how you got here?...

I will send immigration officials after you...

Daniel: $\quad$ (Now sober) Kí lẹ fẹe kí n șe? Kinní yî́ wà unfair o.

(What exactly do you want me to do? This is however not fair).

In È̀̀ku Idà (Sword of Vengeance) (henceforth), Binta is shown to be a young unemployed girl who resides in the Refugee Camp, but not given employment by the Nigerian government. She goes to Chief Bógundé's construction company in desperate need for a means of livelihood.

I am Binta from the Liberian Refugee Camp...

I have Ordinary National Diploma in Business

Administration and Secretarial Studies... Life in the camp

is not easy, I want to earn a living.

Had she possessed relevant migration documents, she would have reported Chief Bógundé's victimization of her to the law enforcement agencies, especially the Human Rights Unit of the UN, when the Chief asks her to leave Nigeria with neither Kòfó their daughter, nor a trace about herself. (Crenshaw, 2002) is right in her observation that: 
... many immigrant women are reluctant to leave even the most abusive of partners for fear of being deported...

Though Bàbá Àkànní (Akanni's father), Ìrètí his wife and Àkànní their son in Àbèní (henceforth to be referred to as $\mathrm{AB}$ ) have neither resident permit nor any traveling document before coming to live in Badiya, a slum in Lagos, Nigeria, then. There he works as a gatekeeper in Chief Bello's compound. This family also returns to Cotonou his former place of residence, when he feels insulted by Chief Bello's vituperation when young Àkànní beats another young boy who was bullying an equally young girl, at Àbẹní's birthday party. This attitude towards refugees can also be read in the way Bùkọ́lá reacts when Șèyí admonishes her to consider having an affair with Daniel, her (Bùkọ́lá's) house help, since she remains barren and her husband has been sentenced to life imprisonment for murder. She responds:

Èèmi?... Daniel?... Daniel... Ọmọ ọdọ̀ mi?

(Myself?... Daniel?... Daniel... My house-help?)

Ó yá, àǹtí Șèyí, ẹ wá máa lọ sílé yín...

(Alright now, aunty Seyi, it is high time you

left for you house)...

This is despite Șèyís explanation that Daniel is handsome and holds a Higher National Diploma from Ghana, that it is the economic conditions in his country that has caused his present situation.

In the same vein, Chief Bógundé in $\mathrm{AB}$, after his supposed 'marriage' to Binta who gives birth to Kofo his only child, tells her to leave the country:

Emeloo ni mofe so fun $e$

pé mi ò lè fé é?

Báwo lo șe rò pé mo

Lè fẹ aláilárá sílé gẹgé bí ìyàwó?

(How many times do I have to tell you that I cannot marry you?

How on earth could you think that I can marry a total stranger like you as a wife?)

Chief Bello as a Nigerian and a bonafide citizen of the host-community to Àkànní's family, way back when Àkànní was just a kid and his father a gate keeper in his (Bello's) household, violates Àkànní's human rights many years later, even as a successful and grown up business magnate. Chief Bello has him locked up in the police cell for daring to attempt to date Àbè̀ní his only child. The reason for his attitude is to ensure that Àkànní remains behind the bars while Àbèní is in the marriage registry (under duress) to exchange marital vows with the son of Chief Bello's friend and business financier.

Chief Bógundé too in El violates Binta's human right to no limit. Capitalizing on the young woman's desperation as an unemployed refugee, he offers to marry her. He thereafter turns her to a complete full-time housewife, living in solitude, under a fake identity. He tells her:

I am going to marry you... I will give you all need...

no wife of mine works. You must not have friends...

I am changing your name... I am going to call you 'Kúnbi'...

Daniel's violation in Bùkọ́lá's household in AMO is very similar to Binta's. Despite his (former) status as a graduate back home in Ghana, he is a steward in Biọdún and Bùkọ́lá's household. As a result of the silent grudge he nurses for Bíọdún's usurpation of Kofi11 junior's paternity and 
calls the toddler "Opemipo"12, he becomes withdrawn and does not do the household chores as he used to do, before Biộdún's incarceration. Bíọdún is enraged when Daniel brings just one bowl of water to the dining table for the couple to wash their hands after their meal. Bíódún shouts at him.

Daniel?... Daniel... Ò ń kà mí lóhùn àbí?

Kí lò ń șe náà láti ìgbà tí mo ti dé?...

Àbí o ò gbádùn ni?... șé èmi ni mo gbà

ẹ́ sílé tàbí ìwọ lo gbà mí?... Tí o ò bá

lọ change, màá lé ẹ dànù... Infact, lọ

kó gbogbo ẹrù ẹ kóo kóra ẹ jáde

nínú ilé yî́ right away...

(Daniel?... Daniel?... You are pretending not to have heard me? Why your sudden change of attitude since my return? Are you out of your mind?...Was I the one who employed you or have you now become my employer? If you do not have a change of attitude, I will sack you. In fact pack your belongings and leave now!...)

Bùkọ́lá is unable to explain the situation to her husband for fear of stigmatization in the patriarchal society they both live. The fact that Bíọdún is not healthy enough to father a child (which he is likely to be aware of) cannot be ruled out ${ }^{13}$. How on earth could Kofi junior resemble relations on Bíódún's maternal linage? He says when he sees the boy for the first time:

À bẹeè ri? Èmi ló jọ o... Pupa tìe ló mú, àmọ́ etí yìí, bí etí àwọn mother side mi șe máa ń rí nìyẹn... 0 seun gan-an ni...

(Don't you see? I am the one he resembles. His fairness is from your end, but these ears, they are like those of my maternal relations... Thanks a lot)

The height of the violation of human rights experienced by Daniel in AMO is the denial of the fatherhood of Kofi, when Daniel expresses his intention to take the child home as he had promised his aged mother, who is waiting to see her grandson before she goes to her grave. Șèyí shouts him down and says:

... Ó tó ẹ bẹeẹ. Oore la ní kí o șe o. Gbọ́ o, kò sí 'junior', kò sí 'Bùkọ́lá' nibi kankan mọ́ o. Sọ fún mama ẹ bẹệ... Get your load and go back to Ghana. Kílo tún fẹ́? We settled you, big time... we improved your life...

(...Keep quiet. You were employed to render help... Listen very well, no more 'junior', no more 'Bùkólá' anywhere, any longer... Tell your mother that... Pack your things and return to Ghana. What else do you want? You have been paid off with heavy some of money... We have elevated you in life...

Daniel of course is extremely sad and he becomes desperate.

Refugees are also very vulnerable to exploitation concerning wages and even in their day-today financial dealings with some unkind and opportunistic members of the host-community ${ }^{14}$. In desperation to earn a living, Binta the Liberian refugee tells stone-hearted Chief Bógundé:

I don't mind any type of job,

I just want to live on my sweat...

Her candidness spurred Chief Bógundé into action; to make her "sweat" on his bed in order to produce a child, for he has no wife, since women cannot live with him because of his nefarious activities. 
The economic depression in Ghana, which sent Daniel and Kwesi his childhood friend to Nigeria, exposed them to receiving menial job offers despite their possession of Higher Diploma. Kwesi becomes a local laundry operator, while Daniel condescends to becoming a house-help in Bíọdún's household. In AB, Lákú, Ògàgú his friend, go to a canteen for lunch in their new open-roof saloon car, to the amazement of the chefs and bystanders. The two chefs agree to charge the new customers exorbitantly for their meals - poison etpoulle (fish and pounded yam).

Attempts by refugees in the films under study to prove or exert their rights and freedom are met with fierce opposition, threat and even death. After many years of sojourn in Nigeria as Chief Bógundé's wife and thus a 'citizen', Binta in El refuses to heed Chief Bógundé's threat. A Yoruba adage is relative here, it goes thus:

Tí ẹrú bá pẹ́ nílé, á á bú alájọbí.

(When a slave stays too long in a household,

he is likely to swear by consanguinity).

Chief Bógundé asks Binta to leave Nigeria and grant him the custody of Kòfó their daughter. He asks Binta to choose any country she wishes to relocate to at her own price. Binta remains adamant.

Mo șetán láti lọ, pẹ̀lú ọmọ mi... Mi ò nílò owó yín... Èmi àti Kòfó la jọ ń lọ...

(I am ready to leave, with my daughter...

I do not need your money...

It is Kofo and myself that are leaving...)

Chief Bógundé swears:

You want to be stubborn, isn't it?

Wa a tesi i.

(You will regret this)

The Chief send hired killers after Binta and she is murdered in cold blood late one night in Kòfó's presence, just few days after her confrontations with the father of her daughter.

Daniel is declared wanted 'dead' or alive by the Nigerian Police Force and Nigeria Immigration Services when he forcefully expresses his human right in desperation, by absconding with Kofi junior, his biological son, begat by his former employer's wife, in the film AMO.

In the films being studied, both men and women no doubt go through tribulations, denials, rejection, incarceration, violation and ridicules. However, the females suffer the worse fate. No male is killed. Daniel and Kwesi in AMO eventually returned to Ghana and by the hands of fate, Kofi re-unites with his biological father and this makes Bùkọlá to bid farewell to her fruitless marriage to Bíódún and joins her son and his father in Ghana. In spite of all Chief Bello does to Àkànní in Àbẹní, he achieves his desire by eventually marrying Àbẹ̀ní his first love and they give Bello and his wife their first grandchild. A deep analytical reading of the three films shows that it is the female who suffer more. Binta, the innocent Liberian refugee is saddled with raising Kòfó alone. As if that is not enough chauvinism, Chief Bógundé sets his men after her and they send her to an early grave in El, because he does not want his 'image' tarnished for marrying a refugee. 
When Daniel absconds with Kofi his son, he goes to hide in Kwesi's apartment. Kwesi advices him to return the child to his parents. This infuriates Daniel, who swears with the last blood in his veins, that he will get his son to Ghana. The two friends, well aware of the fact that Daniel's photographs and that of the child he 'kidnaps', have been pasted all over the town and at the Benin - Nigerian boarder, push the dangerous burden on unemployed and husband-dependent Rebecca, Kwesi's wife. She is the one who carries the child with the intention of crossing the border and escaping to Ghana, where she will be joined by Daniel and Kwesi. Hearing gun shots being exchanged between vehicle smugglers and customs officers, Rebecca becomes restive. She gets down from the vehicle where is and takes to her heels with Kofi in her arms. While running for dear life, stray bullets hit her and she drops dead, holding weeping Kofi to her side.

Women's hands are the ones that rock the world's cradles. Whatever happens to a wife or mother is bound to affect her child/children. The children of refugees are directly or otherwise affected by the situations of their mothers (and fathers, anyway), either, positively or adversely. Kòfó in El misses the naturally expectant fatherly role in her life. She misses her father's presence and love as a young girl. When she follows her mother to where her father resides, she asks in near tears:

Mummy,kí ló dé tí àwa kò fi gbé pẹlú daddy?...

(Mummy, why are we not living in the same place with my daddy?...

This is an obvious denial of a child's right under the laws. Chief Bógundé throws this right to the winds with a wave of hand by asking Kofo to go and meet the steward and ask for whatever she may want to eat and drink.

Binta's death and Chief Bógundé's negligence of his fatherly role exposes young Kofoto a lot of hardship, molestation and violation. By the kind hands of fate, she meets Banji the son of Isola (one of Chief Bógundé's employees) and Débísí who he (Chief Bógundé), had earlier killed as a result of a misunderstanding concerning the sharing formula of a business deal that Isola executed on Chief Bógundé's behalf. Bánjí leaves the motherless home where he lives, goes to the street and there he meets Kòfó. He takes her in with him into the shanty where he lives, like a junior sister. There, Kòfó suffers humiliation, rape attempt and victimization from other males living with Banji. She could have been saved from these sad experiences if the mother is alive and not a refugee.

Young Kofi is found beside Rebecca's corpse by Gandonu, one of the smugglers who are exchanging gun shots with the customs officials. Having no child of his, he rescues the boy and takes him home to his wife in Cotonou, to be raised as their first son. The boy grows up and he is sent to school in Ghana, a neighbouring country. There, Kofi falls in love with Nene, Daniels' niece. Through the girl, Daniel meets his long lost son. Before then, Kofi suffers a lot of mental torture by trying to give meanings to his relationship with 'three fathers'; Bíódún, Daniel and Gandonu. He becomes depressed, especially by his 'stepmother' Remi's attitude after Gandonu's death. She refers to him as "a child that was found by the road side and brought home to inherit a legacy to which he has no legal right". He knows no peace until he is told by Daniel and Bùkọ́lá that they are his real parent.

\section{CONCLUSION}

In this study, we have attempted to examine the seamless movement of citizens of West Africa as they transverse their coastal areas trading, taking up paid jobs, dwelling therein and even dared to cross the Atlantic in exploration for further and better survival. All these were before the assimilation of their land by European colonists, for economic and political benefits. The colonization of these West African states had, and still continues to have adverse effects on the 
political, economic and social life of the people. These have brought about unrests, coups, wars, political instability and thus migration of the younger generation out of their homeland, in search of better and safer living condition. Their experiences as migrants/refugees in Nigeria, the supposed 'giant' of Africa, as they are portrayed in (Yoruba) Nollywood films, has been the major focus of this paper, using three particularly selected films for exemplications.

We have brought to the fore, that Africans generally are warm, homely, kind and hospitable people; essential virtues that are expected of the Yoruba Omoluwabi. However, their impoverishment by the colonists has lowered the normal tempo of kindness, warmth and hospitality toward their kith, kins and kindred in times of need. Apart from this, the age long existing patriarchal ethos which had been very pronounced in the African societies, make the female more vulnerable to this said cruelty, coldness and inhospitality as refugees in Nigeria. Automatically, the said experiences of these women affect their children adversely. The psycho-social and economic impoverishment of the people has brought about changes toward migrants from other West African states as revealed by the selected films studied. In effect, the general human rights violation and denial, victimization, rejection, xenophobic attacks and even death as they are common towards migrants in the West, are being experienced by West Africans from their own people.

It is our recommendation that the Economic Community of West Africa States (ECOWAS) ensure that political leaders and all other stakeholders in West Africa, do the needful to return the Region to its lost glory, put machineries into motion for peace and security and bring about positive changes that will augur for functional education for all; and especially the girl-child, empower the females, create employment for graduates and other school leavers. They must also put in place improved social amenities, meaningful agricultural techniques, memoranda of understanding that will attract investments in the Region by multinational investors and peaceful co-existence among the different ethnic and sub-ethnic groups in the West African countries.

\section{Note}

1. Visit http://en.wikipedia/wiki/immigration statistics.

2. Visit www.premiumtimes.ng.com

3. Visit www.vanguardngr.com/2017/03/xenophobic-attacks-persits-south-africa.

4. This is usually seen as 'creativity'.

5. 'Auters' are film producers who adapt existing written texts, often because of their popularity, for filmic purposes. See Adagbada (2008).

6. Such books, journals and periodicals include Samuel Johnson's History of the Yoruba, Akintoye's A History of the Yoruba, Oba Akínyẹlés İtàn İbàdàn, different series of the YORÙBÁ,LÁǸGBASÀ, Historical Society Journals, Google Wikipedia, Yoruba Encyclopedia and the likes.

7. Ėèku Idà means the 'handle of a sword'. The title of this film is in relation to the Yoruba proverb; Tí ôwó ẹni kò bá tí i tẹ èèku idà, a kì í bèèrè ikú tó pa baba ẹni, (Until one is sure of his weapon of revenge, one should not enquire about what killed one's father).

8. 'Àbẹ̀n'i is a name for the female among the Yoruba. It is more often used as àpèjé/oríkì (panegyrics).

9. Lákú and ọggàgú for instance are characters in Àbẹní, who are University drop-out from America. They return home and engage in cybercrimes. The global communication Technology of that (pre-independent) period was not used for criminal activities, if at all they existed in West Africa. 
10. Films too can be read like texts or other printed matters. Film reading goes beyond viewing for entertainment, it implies critical viewing or watching for review purposes. See Adeleke (1995).

11. 'Kofi' is a common Ghanaian name for a male child born on a Friday.

12. 'Opemipo' means 'my gratitude has no limits'.

13. Despite several copulations during their many years of fruitless marriage and the illegal sexual escapades they have in the compromising Warder's official resident in the prison yard, Bùkọ́lá does not get pregnant for Bíọdún, not even when place on orthodox and traditional treatments.

14. See Mafleet 2002:78

\section{References}

Adagbada, Olufadekemi (2008). "Yoruba Texts on the Screen". Africa through the Eye of the Video Camera (ed) Ogunleye Foluke. Manzini: Academic Publishers: 182-197.

Adagbada, Olufadekemi (2014). “Crime, Image-laundering and Re-absorption”: Eight Years After Wunmi's Egbobi Oloro". Akungba Journal of Linguistics and Literature. Department of Lingusitics and Languages, Adekunle Ajasin University, Akungba-Akoko, Nigeria. (5) 1-14.

Adeleke, D.A. (1995) “Audience Reception of Yoruba Films: Ibadan as a case study”. PhD Thesis, Department of Linguistics and African Languages, University of Ibadan, Nigeria.

Akintoye, S. A. (2010).A History of the Yoruba People.Dakar: Amalion Publishing.

Akinyele, I.B. (1911). IweItan Yoruba. Ibadan: Board Publishers

Bamidele, L.O. (2000). Sociology of Literature. Ibadan: Stirling-Hoden.

Castle, S. (2000) "Citizenship and the other in the age of migration". Ethnicity and Globalization (ed) Castles, S. London: Sage.

Cohen, Robin (2006). Migration and its Enemies: Global Capital, Migrant Labour and the Nation State. Aldershot: Ashgate.

Crenshaw, Kimberle (2002) "Mapping the Margins: Intersectionability, Identity, Politics and Violence against Women of Colour". An Introduction to Women's Studies: Gender in a Transnational World. (eds) GrewalInderpal and Kaplan Caren, New York: McGrawHill: 207-213.

Falola, Toyin (2012).Atlantic Yoruba and the Expanding Frontiers of Yoruba Culture and Politics.Ibadan: Odunjo Memorial Lectures. 2012

Grewal I. and Kaplan C. (2002) (eds) “Gendering Globalization: An Introduction to Women's Studies, Gender in a Transnational World. New York: McGrawHill: 409 - 413.

Haralambos, M., Holborn, M. and Heald, R. (2008) Sociology: Themes and Perspectives (7thedn). London: HarperCollins.

Ilesanmi, A.P. (2016). "The Migration Patterns and Identity of the Okun-Yoruba People of Central Nigeria”. Yoruba Studies Review. (eds) Falola Toyin, Oguniran Akin and Akinyemi Akintude. Texas: Yoruba Studies Review. 1(1). Fall, 2016.: 105-121.

Johnson, Samuel (2001). The History of Yorubas (Reprint) Lagos; CSS Bookshop.

Loomba, Ania (2005). Colonialism/Post Colonialism: The New Critical Idiom. (2 ${ }^{\text {nd }}$ edn). New York: Routledge.

Marfleet, Phil (1998) “The Refugee”. Globalization and the Third World (eds) Ray Kiely and Phil Marflect. London: Routledge.: 70-71.

Potts, Lydia. (2002) "Excerpt from the World Labour Market: A History of Migration”. An Introduction to Women's Studies: Gender in a Transnational World. (eds) GrewalInderpal and Kaplan Caren. New York: McGraw Hill.: 440443. 


\section{Videography}

Abeni (2006). Produced and Directed by Tunde Kelani. Mainframe Production.

Eeku Ida (Sword of Vengeance) (2002). Produced Directed by Tunde Bamisigbin. Rockview Production. Aya mi Owon (Madam Dearest) (2005). Produced and Directed by Tade Ogidan. OGD Film Productions. 